頭 部 CT 像

一第 1 部一

小林 直紀

\title{
Cranial Computed Tomography
}

- Part I-

\section{NAOTOSHI KobayashI \\ Department of Neuroradiology, Neurological Institute, Tokyo Women's Medical College}

1972年に Hounsficld によって EMI-scanner ${ }^{13) 73}$ が開 発されて数年の間に, computed tomography (CT) は全 世界に普及し，媨疾患のX線診断の中で大きな部分を占 めるに至った。このよに短期間に広く普文し，1つの診 断体系の変革をもたらす上らな医療器機汪他化例を見な い.これには radioastronomy $\mathrm{y}^{2}$ や electromicroscopy ${ }^{53} な$ と，また isotope scanningに抢ける ${ }^{6)}$ 電子工学的な, 特に 画像再構成上の先人の努力が大きく寄与している，CT はこれまでのX線写真とことなり，多方向加ら得られた プロシェクションデータ在もとに電算機によって原像の 復元が行われるが，この点仕 CT 像を理解するうえで常 に念頭においておく必要のあることである。

\section{I 正常 CT 像}

血管撮影や気脳撮影などこれれでのX線診断では脳 表面あるいは内面の像上り脳実質内の病変が推定される のに対し，CT では病変そのものが䅐覚的にとらえられ 5る.したがって, 病変の存在骖断に関してはCTは血 管撮影や気脑撮影上りる数段秀れているといえるが，脳 内のgeometryに関しては血管撮影による万が理解しやす い場合がしばしばある。脎の载面における脳内各構造の 分布は解剖書にゆずりここでは CT上の部位判定の要 点定述心吕。

\section{1. 解剖学的部位}

CIにおける部位の判定には, 頭蓋骨, 脑室, 脳槽,

一部の灰白質などが目標となる。

頭蓋骨では，下部では大後頭孔，側頭骨錐体，中頭蓋
前壁, 蝶形稜, 前後床突起が, 上部では前頭および後頭 稜，蝶形頭頂溝が目標となる。

眇室系忟脳内の geometry を判定する上でのもっ上も 大きな目安である。媨空系の各部分と各葉との関係, 鉌 との関係，神経楾維束の走行との関係を明磪に把握して おくことが重要である．CRT上に表示される slice面の 高さのみを基準にして部位の判定を行らと，時に大きな 誤りを犯すことがある。．また，スライスの高さや傾きの 微妙な違いによって現れる像も異なってくるので，正常 構造の正しい認識の上で部位の判定が成されることが望 ましい.

脳槽系では，後頭蓋窞では橋前槽，小脳橋角は全例に 見られるのに対し，大膊槽，小媨谷は見られる頻度は少 ない，テント上では視神経槽およびその外側切痕，脚間 槽, 中媨周囲脳槽，四丘体槽は全例に見られ，部位判定 の大きな目安となる。これに対し，シルビウス裂，脳溝 および半球間溝の出現は個人によってまた年令によって も異なる(図 1 ) .

脳奏質内では白質と炏白質がX線吸收值の違いとして 認められるが，寸べての部位でこの区别が可能なわけで はなく，現在市販されている器譏では基底核部において のみ可能である(図 2 )。尾状核頭部および尾部，視床 がそれより低いX線吸收值を有する内包の前後脚，膝部 によって被款内側と区別される，被款外側は一般に不 明睹でその輪廊を見ることはできない，大脳半球での白 質と灰白質の区別は一般には不可能である、大脳周辺部 では標示されるX線吸収值は本来のをれより高い（pe-

東京女子医科大学脳神経七ンター, 神経放射線科

[速絡先：干162 東京都新宿区市谷河田町 10 , 東京女子医科大学腦神経せンター, 神経放射線科, 小林直紀] 

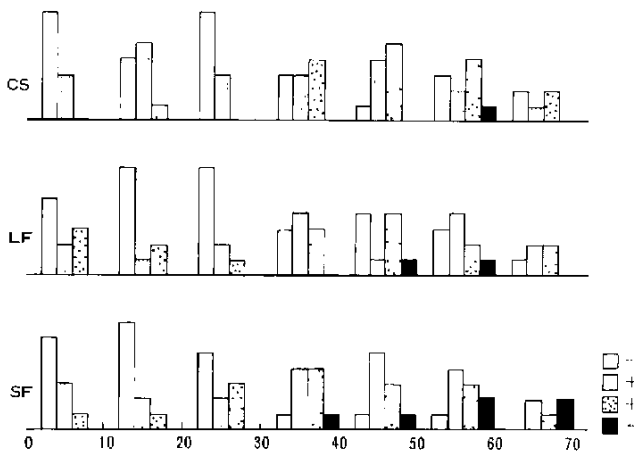

図 I 脳洪 (CS)，正中裂 (LF) シルビウス裂 (SF) の

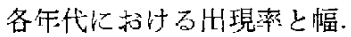

（一）はまったく見党ないもの（土）部分的に見 えるすの，(十)法楾状にほぼ全長にわたって見え

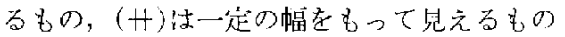
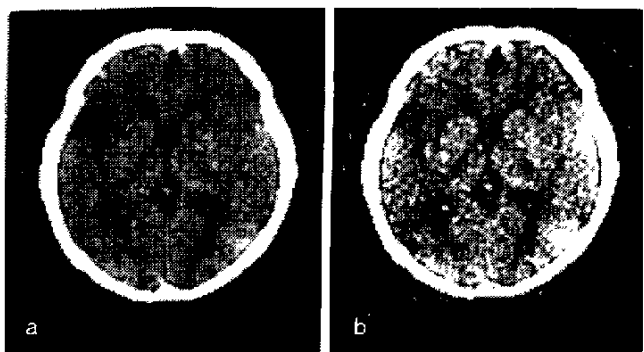

図 2 基底核レベルの让常 $\mathrm{CT}$ 像、a) はコン: ラストの低い真，b)はコントラストを上げて上 られたもの，星状核影部执よび視床が帯状の内色 の低收収層によって被設内側線と区別されて見ら 光る

ripheral high density zone $)^{4}$. 場合によっては EMI-常 数で+40以上を示すことが如り，周囲頭蓋骨の影響と考 えられる。その他，部位によって時に高いX線吸収值老 示すものとしては小檤出部がある。

大脳半球では部位によってX楾吸收值がやや異なった 抢り，前頭部や倒頭部では全体にやや小さく，後頭部さ やや大きいこれは，可一ースライス内に含まれる灰白質 成分り多基に上るもの上考光られる，後頭葉では頭頂後 頭裂や鳥距满汃深く，しかもこれらが问一スライス内索 斜めあるに经汪平行に横切るために灰白躓成方が多く なる。

\section{2. 血管支配領域亡 CT 像}

造影阂意投与しないCT像では，60\%に媨底動脈が上 部橋前槽に認ぬられ，トルコ鞍上部およびその外㑬切痕 (シルビウス慜) 内に脳底部動脈輪の一部や中大脳動脈 水平部が部分的に見られる場合がある。しかし，その他

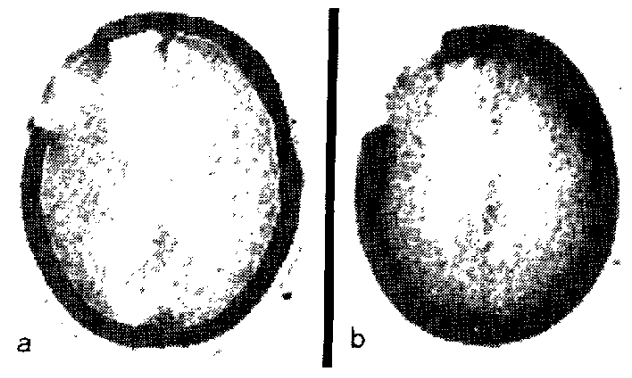

图 3 左前大脳動脈領域の梗塞像，a）側脳室体部 レベル，b) 侧腷室体上部レベル
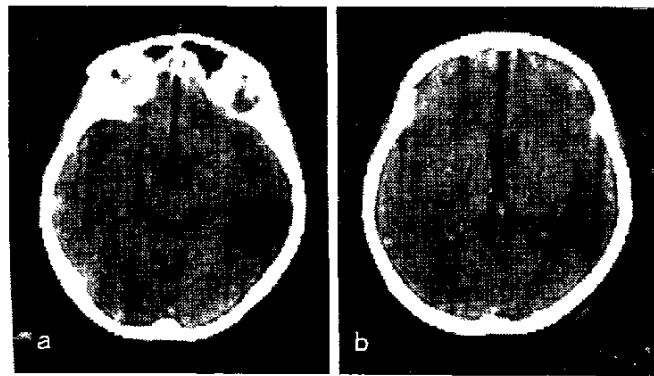

図 4 不後側䫓動脈領域の脳梗塞像。a) 第 3 脳窒 レぶル，b）基底核レベル，前方の吸収值が不整 な部分性前中㒋頭動脈の領域

の血管は一般的には認められることはない，

血管の支配領域付主に譄室との関係で理解して扝くの が便利である。

前大脳動脈法側脳室前角の前方および体部の上方を栄 養し，その領域は大脸半球内側面に接して，これより大 脸半球最外側部なでのほぼ1/3である(洞3)。CT上で 見的る前大脑動脈各分枝の支配領域は，乙の分岐状態 が複雑なために前後の関係掞よび上下スライスよの関倸 で推定されるるに過ぎない。

前頭部外側（側譄室前角外侧）， pterion 前力は orbitofrontal artery, 中脳执よび第 3 脳室レベルの外側，书 上び基底核レベルのシルビウス裂外側は中大脑動脈下行 枝, anterior 执よび posterior temporal artery によって支 配される（図 4)、侧递室体部しべルおよびそれより上部 のレバルの側脳室体部外側では，pterion前力，側脑室解 的の尾状核頭部による indentation の前方は prefrontal arteryによって栄養される。側脳室体前部执よび前任後 部，すなわち Monro 孔定中心をる部注 central artcy， その前力は precentral artery の領域である (图5).こ れより後方，側脳室体後部より二角部にかけてはanterior parictal artery 加，二倍最外側部に一致する部分法 

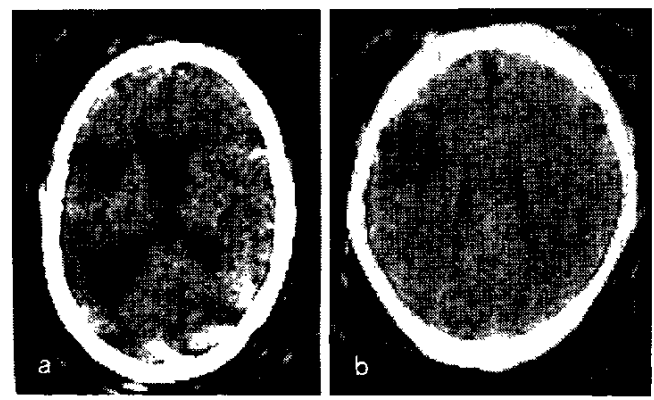

图 5 左中大脳動脈分枝領域の梗基像． a) precentral artery および central artery の特に日立つ低吸 収域が見られる，b) central artery 領域の梗塞像
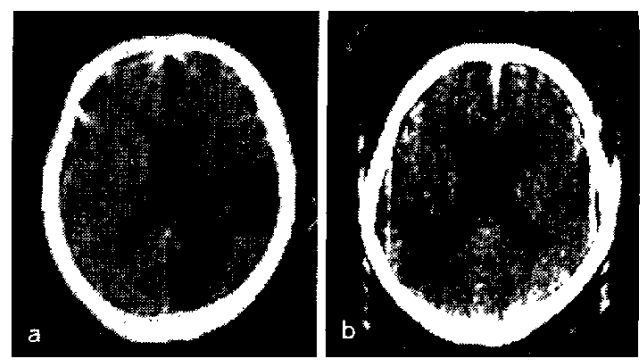

図 6 中大脑動脈分枝領域の梗塞像. a) 在 anterior parietal artery 扩よび angular artery 領域の梗塞 像 (occipital artery 領域の梗塞も見られる)，b) 左 angular 执よび posterior parietal arteries $の$ 領 域の梗塞像

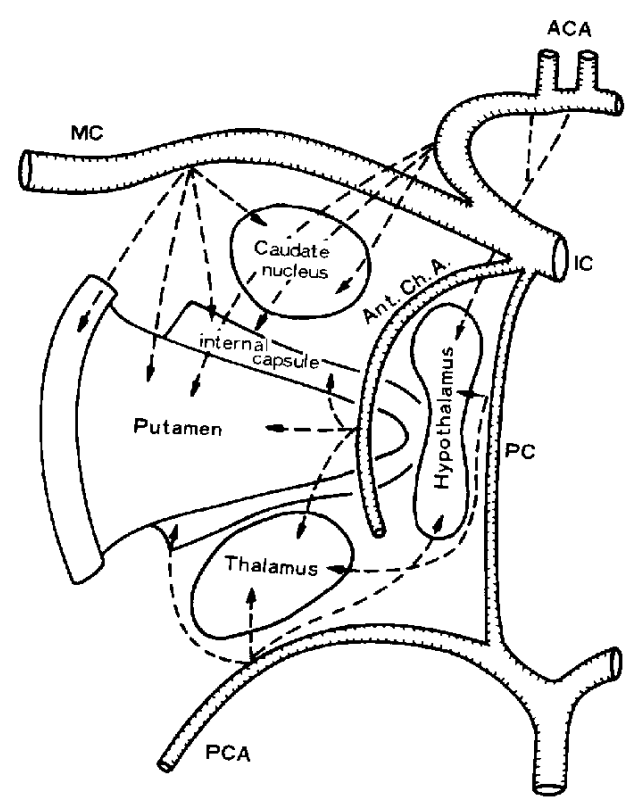

図 7 間脸の血管支配 (Foix et Hillemandょり引用)

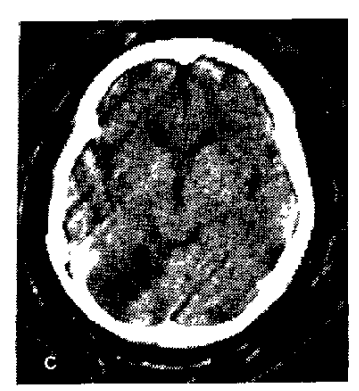

図 8 左上小脳動脈半球枝の領域の梗塞像
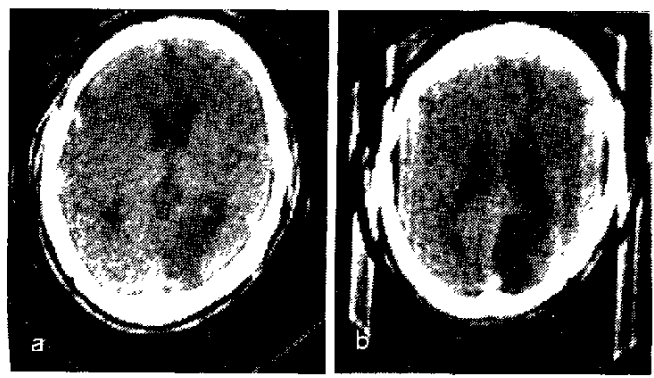

図 9 右後大脳動脈領域の梗塞像，a）基店模レベル， 主に calcarine branche の領域, b) 側脳察体部レ ベル, 主に parieto-occipital branche の領域
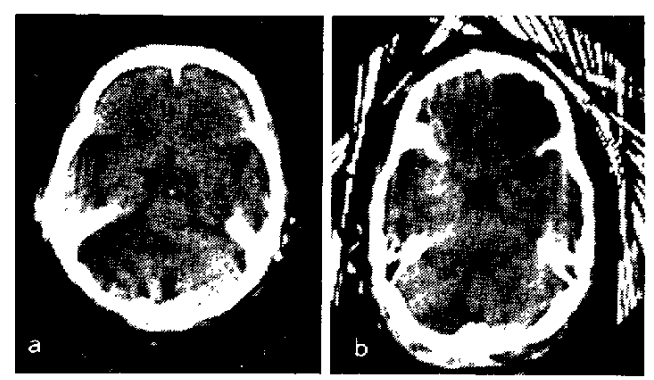

図10 左後下小脳動脈領域の梗塞像. a) inferior hemispheric branche の領域の梗塞像, b) inferior vermian branche (medial branche) の領域の梗塞 像

angular artery が，また，これより後部側䏼室媵南外側 は posterior parietal arteryが支配十る(図6).

第 3 脑公前部外側の視床ド部および基底核部は前大脑 動脈, 中大脳動脈, 前交通動脈, 前脈絡動脈, 後交通 動脈括上び後大媨動脈上り複雑に栄養党けている。 ここで洁 Foix et Hillcmand の模式図 ${ }^{3)}$ 示して扰く (园 7 ).

四丘体槽後部泣中央部でラント上縁が持ち上がってお り，この部では内側に小脳上部，外側に側頭葉が存在す 
る。小脳上部は中央部が上小脳動脈内側枝，外側部が同 上小脳半球枝に上って羲われている(図8). それより 上部の側暚室三角部拉よび後角の内側は後大脳動脈内側 枝に上って栄養されており（図 9)，CT上，後下方は calcarine branche, 上前方は parieto-occipital branch 分布子る。後大脳動脈側頭枝注中媨周囲脳槽外側下面に 分布する.

中脑扩上び橋脳汢上方上り，後大脑動脈，上小脳動脈 および脳底動脈によって栄美される。小脳下部では虫部 および半球内側が後下小脳動脈内側枝，外側注下半球枝 によって栄養される(図10)。これらと前下小腷動脈の支 配領域とは CT 上で判然と区別することはできない： た，これらの血管の起始部に恬種々variationが見られる ので，読影にあたってはこの点索考虑に入れておく必要 がある

\section{3. 神経線維束と $\mathbf{C T}$ 像}

血腫や腫瘍の伸展方向を理解し，他の疾患との監別の ためにも莤内の主な神経線維束の走行を知って拉くこと は必要であり,変性疾患の形態学的診断にも有用である.

\section{II 年令的変化}

脳室の大きさ执よび脳槽の幅は年令的に晎なってお り, 占拠性病変の診断や腷萎縮および変性疾患の診断な ビではこれ考慮に入れておく必要がある。

脳底部媨槽の幅は年令とともに幅大する．シルビウス 裂, 大腷半球間洅怙上び脳瑇は若年者ではその出現率は 低く，その幅む狭いものが多いが，年命とともにその出 現率は增加し，その幅も広くなる(图1)。この程度を 理解しておくことは脳萎縮の程度の診断に有用なだけで なく, 時にX線吸収值の变化のない占拠性病変の存在診 断や広がりを知る上でむ有用である。

上小脳裂は一般には CT上で認内られないのが普通で あり，壮年者以上で時に primary fissure が蚛で諗めら れることがある。

小譄半球外側拉よび大譄半球外側のクモ膜下腔も一般 には認められることはない，CT の機種によっては大脳 あるいは小媨半球外側に線状の低吸収層の認められるも のがあるが，これは画像再構成上の副産物である。

脳室の大きさは年令と相関する。その評価は，Evans ratioその他の気脳撮影上のそれとほぼ同等である。脳室 の幅や脳槽の幅を測定寸る場合，CRTより撮られたフ イルム上で行ら場合と，プリントアウトデータよりその マトリックスの数からなされる場合があり，問題のある ところである. 著者はポラロイドフィルム上で計測して いる. CT 像では一定の厚みを持ったものが平面上に描
写されること，X線吸収值の異なる物澌の接点でもをの 表示される吸收值が clear cutに変化しないことなどか ら，標示された吸収值の違いのみでの計測は不可能であ り，周囲の状況，上下スライスとの関係などより，解剖 学的知識をもとに, CT の機種による画像再構成の方法 の違いをも考虑に入れて計測がなされる必要がある．著 者はこの観点よりポラロイドフィルム上で計測されるの がより正確であると考えている.

基底模部では尾状核頭部や視床の幅（頭蓋幅に対寸る 比率）は特に年令的な変化を示さないが，内包の幅は年 令の增加とともに增加する傾向が見られる（図11）。

$\mathrm{X}$ 線吸收值梳尾状核頭部, 視床, 内包ともに年令的な違 い在有しない(図12).

\section{Partial volume phenomenon および peripheral space phenomenon}

\section{Partial volume phenomenon"}

CT で汢各マトリックスに相当する身体の一部である pixel 内のX線吸收值の総和が，そのマトリックスに表示 される。 したがって, pixel 内の構造と matrix 内の数值 とは無関係である。したがって同一スライス内をある物 質の表面が斜めに橫切る場合には，その部では正確な $\mathrm{X}$ 線吸収值の測定は不可能である。頭蓋底部あるいは密隆 部のスロープが舰㬰質とともに同一pixel 内にある場合 にはこの部の腫瘍の存在を見落す原因となり，側脳室体

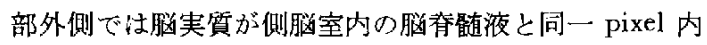
にあり，両者の明膫な区別が困難となる(図13)。をた病 変部辽縁では同様な理由で, 病変部の正確な広がりの判 定を誤る原因となる。

\section{Peripheral space phenomenon}

CT ではある一定の幅をもったX線束で身体を走查 し，これを便宜上一定の大きさを持った絵素 matrix に X線吸収値をあてはめていく方法が上られる。したがっ て，X線吸収值の異なる物質が相接している場合には， その接点で泟確なX線吸収值は表わされないことにな る. 高吸収部では纸く，低吸収部分では高くX線吸收值 が表示される，造影威投与によって enhence された腫㿋 が造影剂投与前の腫瘍より大きく見えるのもこれが原因 であり，一般に吸收值の大きい病変忹笑祭上りも大きく 兄光，小さい病変は夷際上りも小さく見える，EMI$\operatorname{scan}(\mathrm{MK}-1)$ で注，直径 $4 \mathrm{~mm}$ 以下の物質では，それ が slice 内党完全にみたすすのです，その物質の本来の 吸収值は得られない（図14)。中脳水道が CT 上確認で きない理由として，それが slice 内を斜站に横切るため の partial volume phenomenonの一種によるとされる 


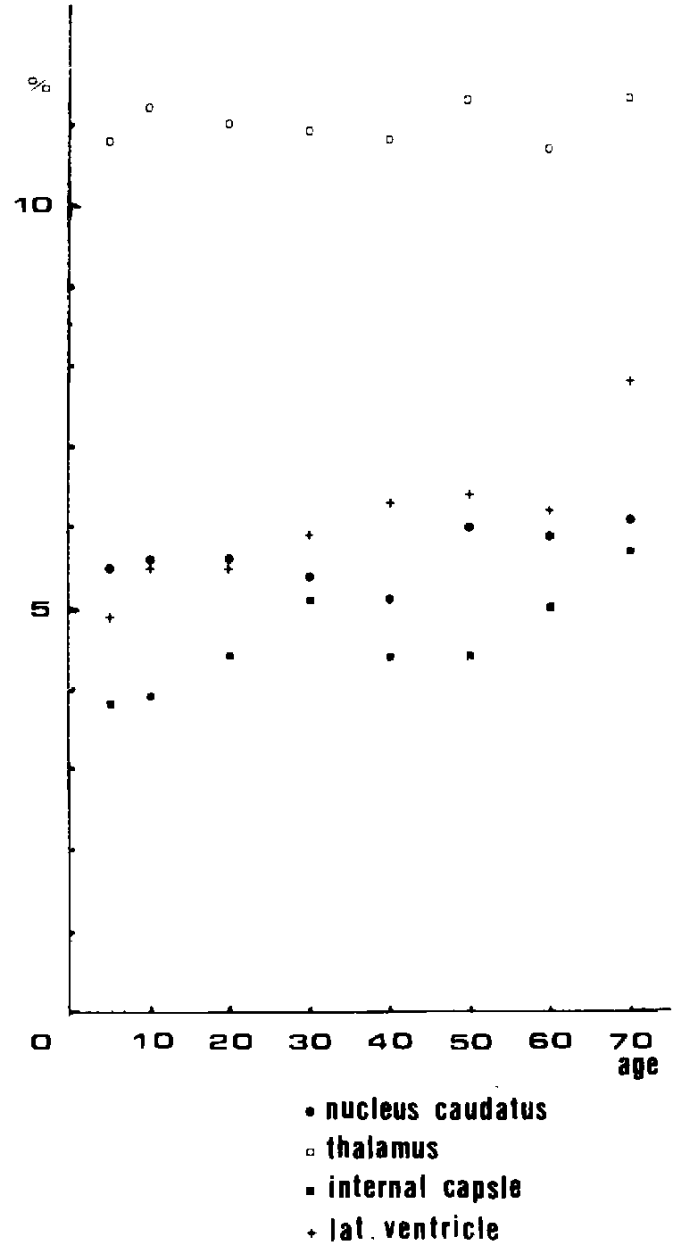

図11 毛状核頭部, 視床, 內包後脚, 側脳室体部 幅（頭蓋最大幅に対するパーセント）と年令との 関倸 (平均)

が，たとえ slice 内にそれが垂直にあっても同定するこ とはできない.小さいものであっても それがX線吸収 值の大きいものであれ壮 CT 上とらえることは可能であ るが，石灰化巣や出血栄索除いて，朕内の病変では䈪実 質とのX線吸収值の羑沬あまり大きくなく，検出可能な たかに注ある一定の大きさ有することが必要である。

この大きさでは partial volume phenomenon も考慮に入 れて, 腫瘍では大体7〜8 mm直径のものだあろう.腫 㾴の場合は，腫瑏そのもののX線吸收值の大きさととも に，周囲脳浮腫の存在による相対的なX線吸収值差の大 きさが問題となる。

\section{Contrast enhancement}

病変部をより明瞭にするために蒀戍を投与し，その部
のX線吸収値を上昇させる方法は contrast enhancement 上呼ばれる. “Contrast enhancement”はをた, 病変部の X楾吸收值が上昇する現象についても用いられる。

Contrast enhancement のための特別な薬剤は現在のと ころなく，一般には血管撮影用の造影剂が径静脈的に用 いら机る。

Contrast enhancement $の$ 因子としては，血管㓐，発達 した vascularity和よび血管外一の造影副の漏出があげら れる.

正常でX線吸收值の堌強するものとしては，血管腔 (脳底動脈輪, 前中後大脳動脈本幹, ガレン大静脈, 直 静脈洞，大矢状静脈洞)，大媨鉡，小媨テント切痕部辺 縁，脈絡叢などがある，脳実質も造影郕投与によって軽 度に上昇し，灰白質の方が白質より強い，部位別で後 頭葉内側宓前頭葉や側頭葉よりも強く増強される れは後頭葉部では同一スライス内に含まれる灭白質成分 が他の部位に比して多いためと解釉される，また，優位 半球の方が対側に比してその増強のされ方が強いといわ れる.

異常では動脈瘤や動静脈奇形が内腔，血㳊内の造影剂 によりX線吸収储が増強する，動脈瘤の場合にはその壁 の増強する場合もある。また動静脈奇形ではそのvascularityの大ささによっても增強が見られる、腷腫瘍，膿 瘍壁は vascularityの增強によりそのX線吸収值は上昇す る、脳腫堭の場合にはこの他，血液脳関門の破糘による 造影剂の血管外漏出によっても增強が見られる。血管外 漏出によって吸收值の增強するむのとしてはこの他，脳 梗塞, 脑内血腫周过, 炎症（slow virus infectiont含む） などがあげられる。

動脈瘤の造影剂投与後のX線吸収值の時間的推移法造 影刜の血中内濃度のそれとほぼ一致して招り，同様の pattern を示するのに铕膜腫上動静脈竹形がある(図15). これらは vascularityが造影剂による吸收值増强に大きく 影製しているためと考えられる。これに対し，gliomaで は，造影郕の一括注入後のX線吸収值は，注入後10 20 分にもっとも高く，以後漸减する。この傾句は glioblastoma multiforme $\beta$ high grade $\sigma$ astrocytoma $に$ 典型的 に見られる。これは，X線吸収値増強に vascularityと血 管外漏出の両者が関与していることを示している，造影 剂注入後遅い時期に行われる delayed scanで，腄境内 部の壊死巣や亭胞が増強されてくる場合がある. Glioblastoma multiformeの高吸収部分と巾央部の低吸收部分 とを分けてX線吸収值の推移を見ると，高吸収部分では 10分前後に最高值に達し，以後漸減するのに対し，低吸 収部分では，造影剂注入後X楾吸収值が漸増士るのが見 
a)

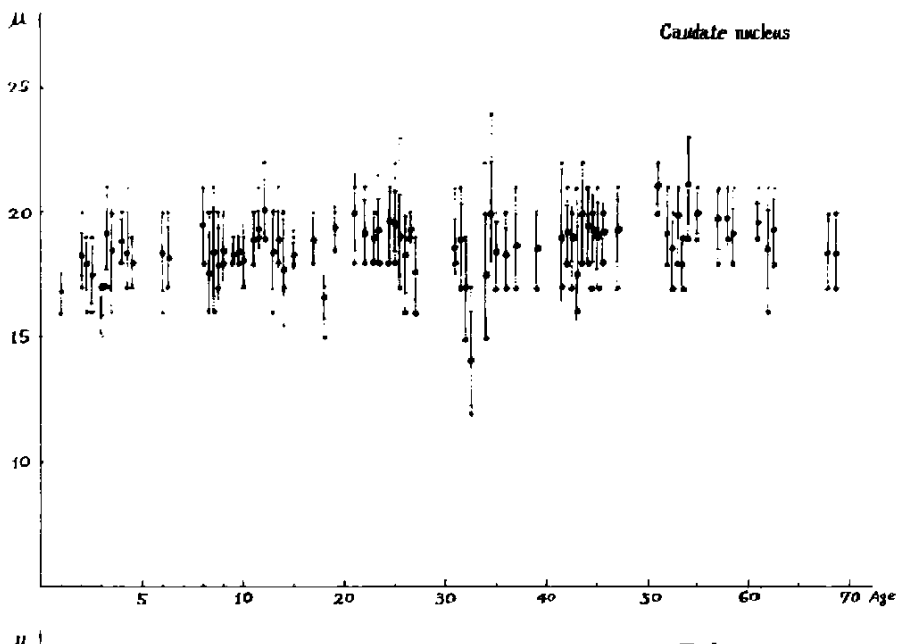

b)

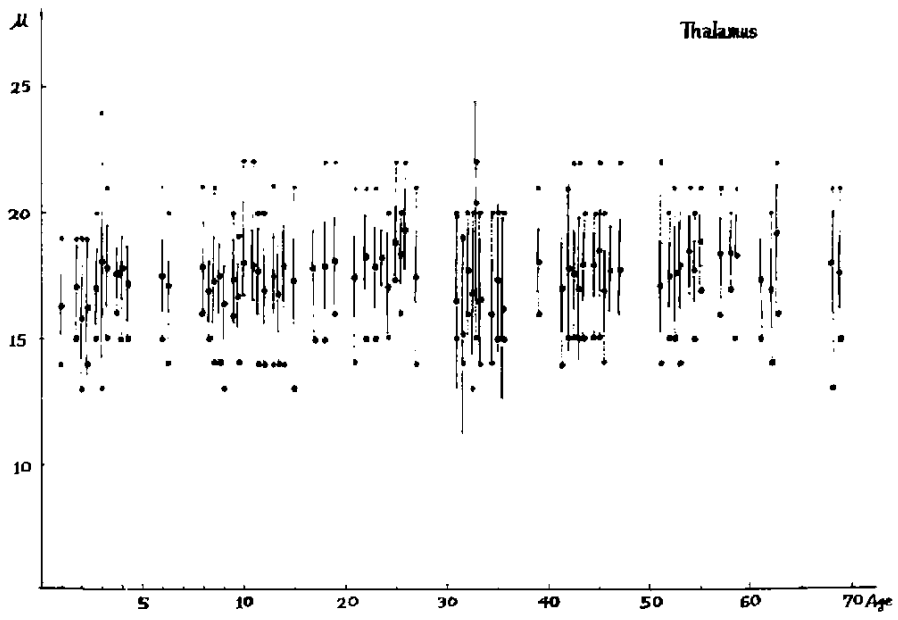

c)

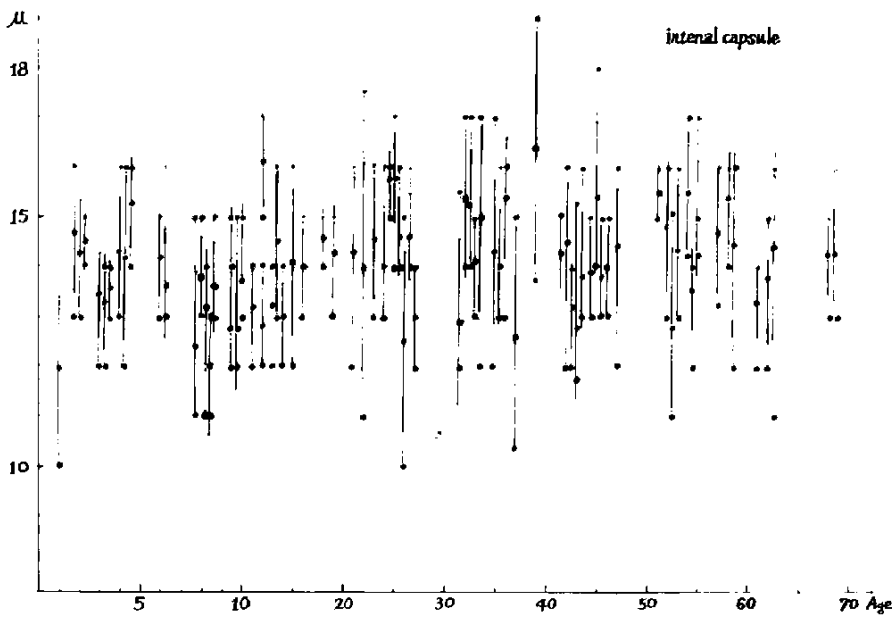

図12 基底核部各構造のX線吸収值（EMIーナンバー）上年令，中央の点は平均，実線上の上下の点汢標淮偏差， 点線上の上下の点は最大值扝よび最小值、a) 芼状核頭部、b) 視床, c) 内包後脚 


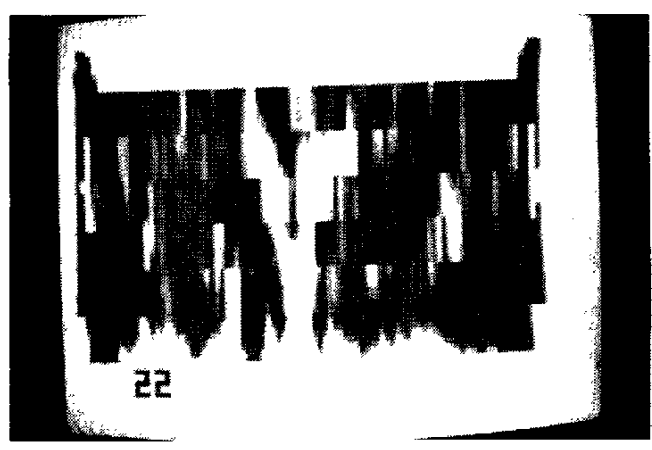

図13 $13 \mathrm{~mm}$ スライスでとらえたスキャン像车 Monro 孔を通古冠状唒で再合成したむの. Partial volume phenomenon している

80

$ス+\square-ル$
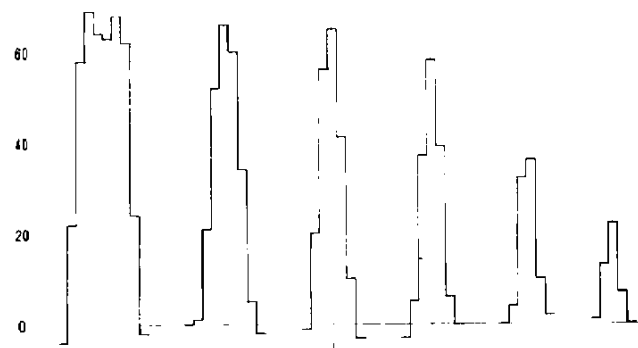

$10.0 \mathrm{mo}$

$5.5 \mathrm{mec}$

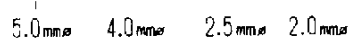

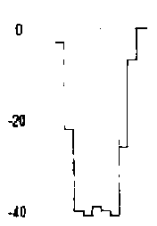

$-80$

ポリエチレン

図14 スチロール(EMI-ナンバー約+60) 打上び ポリエチレン (EMI-ナンバー約ー40)に上る径の 珙なるピンフォントームを水中でスキャンしたと き再生変化

られる(图16)，後者は前述の dclayed scan の鞋合と同様, 造影剂の漏出が吸収值增強の因子となっている。

脳梗塞の contrast enhancement は典急性期すなわち発 作上り 1 週目加ら4週目の問に多く兒られる。この時問 的推移は悪性の神释荊腫と類似しているが，2つの型が 見られ，1 つは glioblastoma multiforme $の$ 高吸収城に見 られるよらに15分から20分後に最高に達し，以後溸減寸 るもので，他の1 つは glioblastoma maltiformeの低吸收 部に見られるよらに，静注後漸増するものである，䏼梗 塞单のCT 像上での正確な広がりの判定は困難なことが

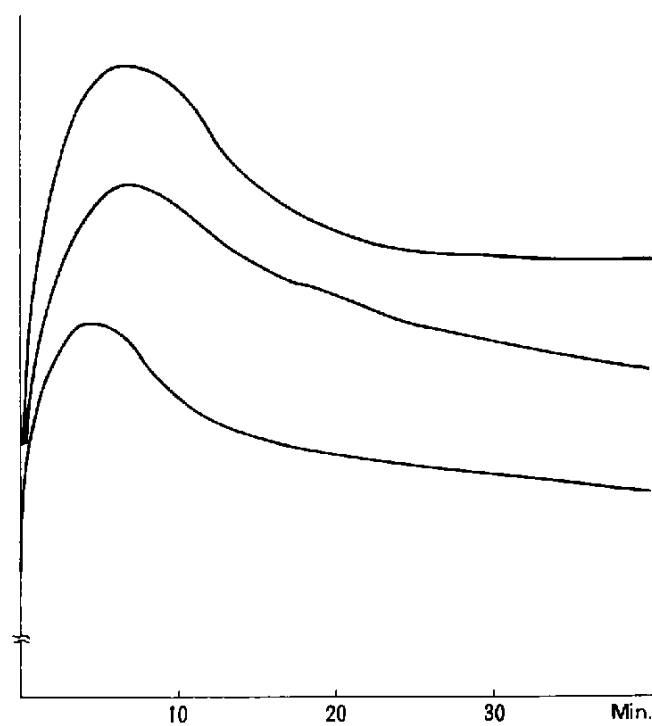

図15 Contrast enhancement における病変のX線 吸収值の時間的推移，上注大動脈瘤，中湿随膜 腫,下注動静脈奇形（造影成は一括注入）

ある，造影剂による増強部分が，造影斉投与前の低吸収 部より小さいもの，同じものおよびより大きいものなど があり，また，投与前にはまったくX線吸収倠の変化が なく，造影剂投与後に始めて高吸収部として現れるもの むむる. Contrast enhancement 上の時間的推移の違いは この梗塞褁をどの範囲で測定するがよっても起こると 考えられる。

病変による contrast enhancement の時間的推移は上述 のよらに多少異なってはいるが，一般にもっとも強い増 强貝るのは静注後10分加ら20分である。 また増強の程 度は投与する造影剂の量によって異なる。血管外漏出に よる増強は造影風の点滴長時間静注によって期待でき, 造影剂の投与方法によっても堌強の pattern は変ってく る. 現在, 投与寸る造影覑の種類, 量, 投与方法, scan 開始時間など，最適と考えられる方法が模索されている よらであるが，著者は検查時閒の短縮，経済性，安全性 などの点より，60\%gulcamine 塩を患者 $1 \mathrm{~kg}$ 当り約 $\mathrm{l} \mathrm{cc}$ の割合で投与し，静注終了直後よりscanを開始してお り，一般臨床上十分その目的索達しえている。

\section{Artifact}

CT では多力向加ら得られる透過X線をもとに，コン ピューターに上って人工的に原像が再構成されて像が得 られるため種々の artifact が発生する。これにはCT に宿命的なものが含なれており，CTの器機によるもの と被写体によるものとがある。 

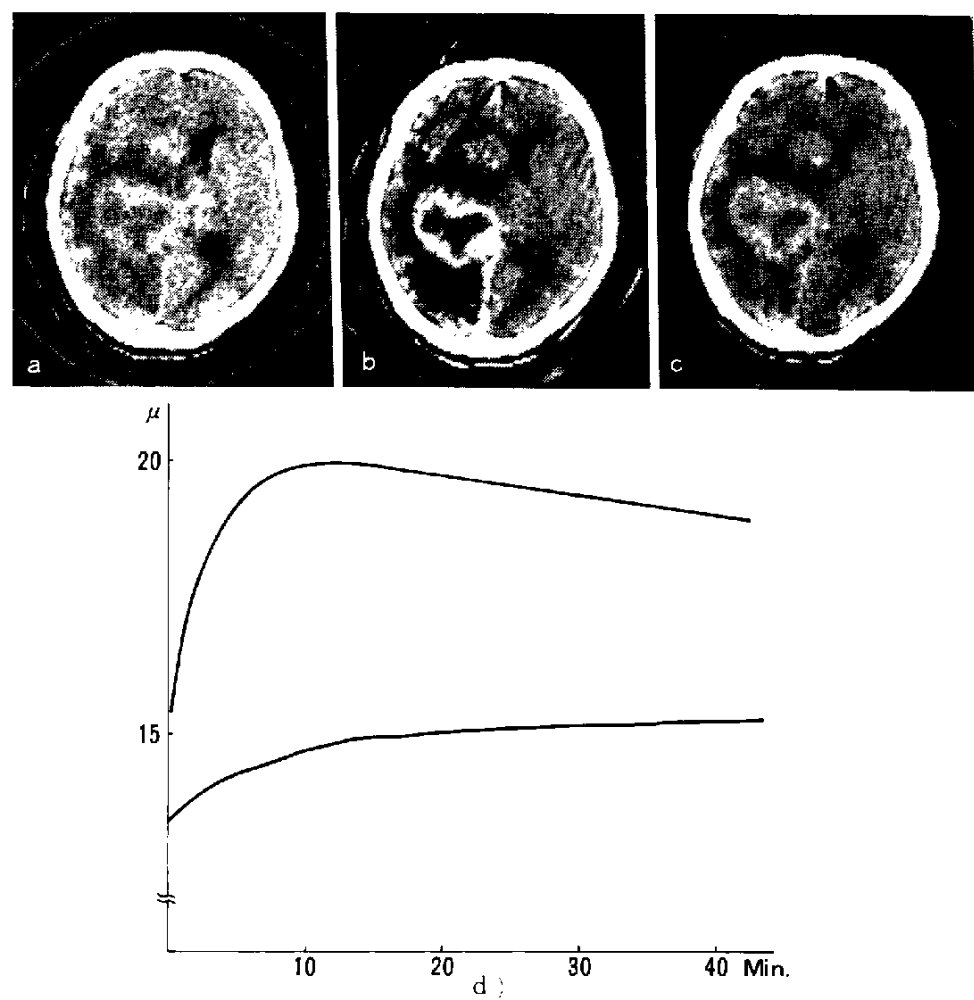

図16 Contrast enhancement による glioblastoma multiforme のX楾吸収值の時間的推移(一括注入)。 a) 造影剤 静注前，b)造影剂静注值㣪. c) 造影剂静注㣪 ] 時間, d) 時間的推移，上は高吸収部分，下は中央部の低吸収 部分の平均 $\mathrm{X}$ 線吸収值

\section{1. 被写体の動きによる artifact}

現在市䝮されているCT は検查時間が名っとも短加いも のでも約 5 秒であり，他のCTではさらに長い検査時間 要する。この間患者在一定の位置に静止しておく必要 があ，意識のない患者や幼小悲ではそれに必要な処置 がとられる必要があり，一般の成人でもよく㗨張を解い て十分な静止老得る必要がある。

\section{2. 頭蓋内外の異常高吸収あるいは異常低吸収物質の}

\section{存在による artifact}

頭䈏内では手術後り金属クリップや気腷撮影あるいは 脳宝掫影後の気体や造影剂の存在に上って起こるskreak ing や over shooting が見られる。これらに対する対策上 して汢特になく，観察したい部位をこれらの異常吸収物 犋が含まれないように slice の位置を設定するなどの消 極的な方法がとられるのみである。これらの異常吸收物 質の存在による artifact の大小患者の動きによっても 影響を受ける。量の金属クリップや油性造影剂は，完 全な患者の静止が得られるなら診診断上大きな障害とは ならない。

頭蓋外の異常吸収物質では Water-bag 索用いる機種で
頭蓋と water-bag の間の空気による artifact がある。骨 久損部の䧄叫部や包帯内の空気が問題となり，同部附近 の頭蓋队のX線吸收值が広範囲に低下寸ることがある。 Water-bag交用いないものでは頭部が gantry内の一方に 片して存在すると，その中央部に近い部分が低吸收域上

して現れることがある。

\section{3. 頭蓋内の部位に特徽的な artifact}

前述した頭蓋骨内側の低吸収屏や peripheral high dcnsity zone は画像再構成の過程で起こる artifact であ る. この頭蓋内側 $の$ 低吸收層江画像再成時 $の$ weighting effect によって起こり機種の違いによって異なってい z.

この他, 部位によって特徴的なものとしては前, 後頭稜 による streaking，前頭蓋低部中央部，中頭蓋窩前外側の 低吸収域，橋上部を横走才る低吸収帯，侧頭骨錐体後部 の高吸収域および頭蓋内側の塊状高吸収城などがある。 こ扎らは被写体の動きにも影響されているのた，病的な ものとの鑑別には再スキャンが有效である。 


\section{VI 従来の X 線診断との対比}

$\mathrm{CT}$ が従来のX楾撮影と異なる大きな違いの1つは， フィルムのかわりにX線の検出をシンチレーション検出 器で行っている点である．したがって微練なX線吸収值 の違いの判定が CTで法可能である，頭蓋内石灭化の場 合ではX線撮影では得られない病巣をる検出することが 可能である.しかし単純撮影では現れないCTーナンバー の石灰化果でも一定の厚双を持ったものでは単純撮影上 陰影として現れる点は，単純撮影との対比の上で知って 抢く必要のあることだある。

CT で注病を視覚的にとらえることができ，脳梗塞 巣や脳浮腫像を啇確に知ることができる。これは気脳撮 影や血管撮影では脳表面あるい緖の内面の様子よりそ の実翼内の状態を推定するのと異なるCTの大きな利点

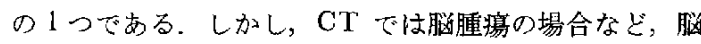
内の目標となる楧造が消失し，その正確な位固の部断や 周囲媨構造との関倸あるいは腫瘍の発生位置および伸展 方向を知るのが困難な場合がある。この傾向は後頭蓋窝 の占拠性病変のときに特に強い8，血管撮影はこの点で 特に重要であり，正確な診断は血管撮影にたよらねばな らない場合がしばしばある。また，CT では描出しえな い脑底部の小さな腫瘍などでは単純写真，気媨撮影ある い恤管撮影によってのみ部断されらるものも多い： たCTで㑇められる病変は周囲の脳組織とX線吸収值の 異なる場合のみであるので，慢性の脑内あるいは硬膜下 血腫では血管撮影によって確定診断がなされる。動脈瘤 や動静脈奇形では血管撮影が唯一の最終診断法であるこ とはいうまでもない。

脳萎縮や変性疾患の形態学的観察は徉来主に気媨撮影 によってなされてきたが，CTによってもある程度は観 察可能である，気脳撮影は患者に与える苦痛が大きく， どこでも正確な診断がなされるわけではないので，特に 変性疾患の場合に，症状発現時にCTによって簡㧘に形 態学的な観察がなされることは臨床的にも，またこの種 の疾患の研究の上でる有州である。しかし，慆溝の場 合，その抬大が気脳撮影によって判定されるのは脱落し
た神释線維の数にして50〜100万本，CTでは500〜1,000 万本といわれており，その正確さについれはこれらの違 いを知って扝く必要がある。

\section{文献}

1) Anbrose, J. \& Hounsfield, G. N.: Computerized transverse axial tomography, 32d annual congress of British institute of radiology. London Apr. 1972, pp 20-21

2) Bracewell, R. N. \& Riddle, A. C.: Inoversion of the fan beam scans in radioastronomy. Astrophysical J. 150: 427-434, 1967

3) Foix, C. \& Hillemand, P.: Les artéres de l'arc encéphaliqul iusqu'au diencéphale inclusivement. Rev. Neurol. 2: 705-739, 1925

4) Gado, M. \& Phelps, M.: The peripheral zone of increased density in cranial computed tomography. Radiology 117: 71-74, 1975

5) Gordon, R., Bender, R. \& Herman, G. T.: Algebraic reconstruction technique (ART) for three dimentional electron microscopy and X-ray photograph. J. Theor. Biol. 29: 471-481, 1970

6) Hounsfield, G. N.: X-ray diagnosis peer in side the brain. New Scientist. 27 (207) 1973

7) Hounsfield, G. N.: Computerized transverse axial scanning (tomography): Part I, description of system. Br. J. Radiol. 46: 1016-1022, 1973

8)小林直紀，小野由子，今永浩寿，山本昌昭， 神保実，喜多村孝一：後頭蓋窝腫瘍に対する EMI scanner (computerized transverse tomography) の診断的価値，踟放，22:57-58, 1977

9) New, P. F. \& ScotT, W. R.: Computed tomography of the brain and orbit (EMI-scanning). Williams \& Wilkins, Baltimore, Maryland, 1976

10) Oldendorf, W. H.: Isolated flying spot detection of radiodensity discontinuities-dysplaying the internal structural pattern of a complex object. Ire Transactions Bio-Med. Electr. 8: 68-72, 1961

11) Zilkha, E., Ladurner, G., Ilif, L. D., Du Boulay, G. H. \& Marshal, G.: Computer subtraction in regional cerebral bloodvolume measurements using the EMI-scanner. Br. J. Radiol. 49: 330-334, 1976 